\title{
DETERMINANTS OF UNMET NEEDS IN MARRIED WOMEN IN INDONESIA (INDONESIAN DHS ANALYSIS 2017)
}

\author{
Bethania Amruh Nisak \\ Faculty of Public Health, Universitas Airlangga, 60115 Surabaya, East Java, Indonesia \\ Corresponding Author: Bethania Amruh Nisak \\ E-mail: bethania.amruh.nisak-2016@fkm.unair.ac.id
}

\begin{abstract}
The incidence of unmet needs in Indonesia is still high, around 10.6 percent. For every 36 million couples of childbearing age, there are 4 million couples who experience unmet needs. The high number of unmet needs will trigger various effects on women of childbearing age. One of the impacts is unwanted pregnancy. This unwanted pregnancy can be a factor in morbidity and mortality in the mother, increasing maternal mortality if not addressed promptly. This study is an observational non-reactive study. This study aimed to determine the factors related to the unmet need for family planning in married women. The study subjects were 29,189 married women aged 1549 years old (women of childbearing age). The data source comes from the Indonesian Demographic and Health Survey (IDHS) in 2017. Further analysis was carried out using the chi-square test and multiple logistic regression. The results show that the factors affecting the unmet need for family planning in women are the age of women, the number of children who are still alive, family planning discussions between spouses or husband and wife, education level, employment status, knowledge related to methods, and history of family planning use. The variable of family planning usage history is the most influential factor in the unmet need for family planning in pregnant women. Women who have never done birth control have a high risk of unmet need — women's knowledge about contraceptive methods related to the contraceptive method and the history of using family planning (p-value $<0.05$ ). The variable of family planning usage history is the most influential factor in the unmet need for family planning in pregnant women. Women who have never done birth control have a high risk of unmet needknowledge related to family planning methods and history (p-value <0.05). The variable of family planning usage history is the most influential factor in the unmet need for family planning in pregnant women. Women who have never done birth control have a high risk of unmet need.
\end{abstract}

Keywords: unmet need, women of childbearing age, history of contraception

\section{ABSTRAK}

Kejadian unmet need di Indonesia masih tinggi sekitar 10,6 persen yang dapat dikatakan setiap 36 juta pasangan usia subur terdapat 4 juta pasangan yang mengalami unmet need. Angka unmet need yang tinggi akan memicu berbagai dampak pada WUS, salah satu dampaknya adalah kehamilan tidak diinginkan (unwanted pregnancy). Kehamilan yang tidak diinginkan ini dapat menjadi faktor kesakitan dan kematian pada ibu yang jika tidak segera diatasi dapat meningkatkan kematian pada ibu. Penelitian ini merupakan penelitian observasional bersifat non reaktif. Penelitian bertujuan untuk memperoleh faktor yang berhubungan dengan unmet need KB pada WUS yang menikah. Subyek penelitian adalah Wanita Usia Subur (WUS) telah menikah dengan usia 15-49 tahun sebesar 29.189 wanita. Sumber data berasal dari hasil Survei Demografi dan Kesehatan Indonesia (SDKI) tahun 2017. Selanjutnya dilakukan analisis dengan uji chi-square dan regresi logistik berganda. Hasil mengatakan bahwa faktor yang mempengaruhi unmet need KB pada WUS adalah usia wanita, jumlah anak yang masih hidup, diskusi $K B$ antar pasangan atau suami istri, tingkat pendidikan, status pekerjaan, pengetahuan terkait metode, dan riwayat penggunaan $K B$ (nilai $p<0,05$ ). Variabel riwayat penggunaan $K B$ menjadi faktor paling berpengaruh pada terjadinya unmet need KB pada WUS. Wanita yang tidak pernah melakukan KB memiliki risiko yang tinggi untuk terjadi unmet need.

Kata kunci: unmet need, wanita usia subur, riwayat kontrasepsi 


\section{INTRODUCTION}

Indonesia is ranked fourth globally regarding the largest population, estimated at up to 269 million people (3.49 percent of the total world population). Indonesia's population based on the 2012 census was 244.2 million, with a 1.49 percent population growth rate. In 2018 it increased to 266.7 million people (Bappenas, 2018). Very high population growth is predicted to occur in the 2030s, creating big problems for Indonesia if it is not resolved immediately. The government issued a policy using family planning to reduce population growth explosion (BPS, 2013). The use of family planning can increase the welfare of mothers and children. This welfare is the beginning of forming a prosperous society through family planning to control population growth (BKKBN, 2009).

The implementation of the family planning program in Indonesia can be pretty successful. The 2017 IDHS says that there was an increase in contraceptive use, which at the beginning in 2012 was 62 percent to 64 percent in 2017. The percentage of Unmet need also decreased in 2017 to 10.6 percent, which was initiated in 2012 amounted to 11.4 percent (IDHS, 2017). However, these results still have not reached the target of the BKKBN, which makes the unmet need 9.91 percent (BKKBN, 2015).

According to the 2017 IDHS, the number of unmet needs in Indonesia is still high, with a value of 10.6 percent of the 36 million couples of childbearing age. It can be said that 4 million couples need contraception but have not been served. The definition of Unmet need is a condition of couples of childbearing age (PUS) who want a specific method or type of contraception but are not fulfilled, so they decide not to use that type of contraception. The high number of unmet needs could be caused by the failure of the family planning program. In the implementation of the family planning program, there are still problems, such as unequal access to family planning services in remote areas, borders, islands, poor urban areas, and the quality of health services that are not optimal (BKKBN, 2018). Unmet need problems are multidimensional which can be influenced by various factors, namely social characteristics, demographics, attitudes, economics, and access to services (Stephenson, Beke, and Tshibangu, 2008).

The unmet need can also be caused by two sides, namely from service providers and users. The service provider here is the government, where they are responsible to the community as users to provide the necessary contraceptive methods. When the contraceptive method that is distributed is not what society wants, it can cause problems. Problems can occur on the client or community side as well, such as a sense of concern about side effects or the occurrence of adverse effects on health and fertility, concerns about methods of lack of knowledge related to contraception, husband's support regarding unmet need behavior, invasive contraception, and discomfort in use. This problem still occurs today, especially in women (Kurniasih, 2014). Unmet need behavior in women who do not want to use contraception even though they need contraception in preventing or managing pregnancy. This behavior can lead to unwanted pregnancies and will lead to abortion.

According to WHO (2013), It is estimated that all women who experience unwanted pregnancies are 34 million people who have unexpected births, 4 million people end up in miscarriage, and 42 million people have abortions each year. This unwanted pregnancy can be a factor in maternal morbidity and mortality caused by unsafe abortion behavior. Therefore, 75 percent of maternal deaths in Indonesia and the world are partly due to many unmet needs. If the unmet need is not resolved immediately, it could increase Indonesia's maternal mortality, estimated to be 359 per 100 thousand live births (Dariani, 2015). This study aims to analyze the determinants of family planning unmet needs in married women based on these problems.

\section{METHODS}

The study used an observational design that was unobtrusive (non-reactive) using secondary data. The data collection source came from the Indonesian Demographic and Health Survey (IDHS) in 2017. The study respondents were women of fertile age (women of childbearing age) aged 15-49 years and married. The sample size used was 29,189 married women who did not involve couples who experienced birth control failure and wives who were menopausal. 
The dependent variable in this study is the incidence of unmet needs. Here, the unmet need refers to women of childbearing age whose family planning needs are not fulfilled. At the same time, the independent variables are the age of women who are pregnant women, education, occupation, age at first marriage, number of children who are still alive, knowledge related to family planning methods, history of family planning use, family planning discussions between husband and wife, and the area of residence. Bivariate analysis used the Chi-Square test, and multivariate analysis was performed using multiple logistic regression tests using a 95\% confidence interval (CI) and a significance level of $\mathrm{p}<0.05$.

\section{RESULT}

Table 1 shows that the distribution of the number of women of childbearing age in the Met Need category $(89.6 \%)$ is greater than the women of childbearing age in the Unmet Need category $(10.4 \%)$. The results of the analysis of the relationship between the independent variables and family planning needs show that there is a relationship between age $(0.000<\alpha)$, family planning discussions between husband and wife $(0.000$ $<\alpha)$, the number of children still alive $(0.000$ $<\alpha)$, an education level $(0.002<\alpha)$, occupation $(0.003<\alpha)$, knowledge related to family planning methods $(0.000<\alpha)$, as well as a history of family planning $(0.000<\alpha)$ with family planning needs in women of childbearing age. Meanwhile, the variable age at first marriage $(0.375>\alpha)$ and the area of residence $(0.146>\alpha)$ did not show a significant relationship with the need for family planning among women of reproductive age (Table 2).

Table 1. Variable Frequency Distribution of Family Planning Needs

\begin{tabular}{lcc}
\hline \multirow{2}{*}{ Category } & \multicolumn{2}{c}{ Family Planning Needs } \\
\cline { 2 - 3 } & $\mathbf{n}$ & $\mathbf{\%}$ \\
\hline Unmet Need & & \\
Family & 3,027 & 10.4 \\
Planning & & \\
\hline $\begin{array}{l}\text { Met Need } \\
\text { Family } \\
\text { Planning }\end{array}$ & 26,162 & 89.6 \\
\hline Total & 29,189 & 100.0 \\
\hline
\end{tabular}

After the chi-square test was carried out, multiple logistic regression analysis was continued. The variables included in the analysis met the criteria in the chi-square analysis $(\mathrm{p}<0.05)$. The variables produced in the multivariate analysis stage through multiple logistic regression analyses were age, the number of children still alive, family planning discussions, education level, and family planning history, which affected unmet needs in married women $(p<0.05)$. Based on Table 3 , the chances of women of childbearing age with age 45-49 years are 1.24 times more likely to experience family planning unmet need than women of childbearing age-aged 15-24. Meanwhile, those aged 25-34 and 3544 have a lower risk of women of childbearing age with ages 45-49. The ages of 25-34 and 35-44, respectively, have the risk of experiencing the unmet need for family planning by 0.73 and 0.88 times greater than those aged 15-24 (Table 3).

The more children they have, the higher the unmet need for women than women who don't have children. The risk of women having 3-4 children tending to develop unmet needs is 0.71 greater than women with 1-2 children or who do not have children. Meanwhile, based on women's education level, women with secondary education backgrounds tend to have an unmet need by 1.08 times than women with high educational backgrounds. This risk is higher than women who have no experience in school or primary education. Women who never used birth control were also 6.27 times more likely to have unmet needs than women who had a history of using FP. As well as women who discuss the use of family planning with their husbands have a lower risk of 0 .

The ideal multivariate analysis modeling yields five variables that are proven to influence the incidence of unmet need. The influencing variables were the woman's age, the number of children still alive, family planning discussions, education level, and history of family planning use. This multivariate analysis can be used to obtain the variable that most influences unmet need in women of childbearing age by comparing the $\mathrm{OR}$ values in the modeling. The variable of family planning use history is the most influential variable 
on the unmet need for family planning. The variable history of family planning use is always significant in each model and has the highest OR (Table 3).

The more children they have, the higher the unmet need for women than women who don't have children. The risk of women having 3-4 children tending to develop unmet needs is 0.71 greater than women with $1-2$ children or who do not have children. Meanwhile, based on women's education level, women with secondary education backgrounds tend to have an unmet need by 1.08 times than women with high educational backgrounds. This risk is higher than women who have no experience in school or primary education. Women who never used birth control were also 6.27 times more likely to have unmet needs than women who had a history of using FP. As well as women who discuss the use of family planning with their husbands have a lower risk of 0 .

Table 2. Variable Frequency and Relationship between Independent Variables on Family Planning Needs

\begin{tabular}{|c|c|c|c|c|c|c|}
\hline \multirow[t]{2}{*}{ Variable } & \multicolumn{2}{|c|}{$\begin{array}{l}\text { Met Need Family } \\
\text { Planning }\end{array}$} & \multicolumn{2}{|c|}{$\begin{array}{c}\text { Unmet Need } \\
\text { Family Planning }\end{array}$} & \multirow[t]{2}{*}{$\mathbf{X} 2$} & \multirow[t]{2}{*}{ p-value } \\
\hline & $\mathbf{n}$ & $\%$ & n & $\%$ & & \\
\hline Female Age & & & & & 44.13 & 0,000 \\
\hline $15-24$ & 3,339 & 11.4 & 447 & 1.5 & & \\
\hline $25-34$ & 10,099 & 34.6 & 1,036 & 3.5 & & \\
\hline $35-44$ & 9,917 & 34.0 & 1,129 & 3,9 & & \\
\hline $45-49$ & 2,807 & 9.6 & 415 & 1.4 & & \\
\hline First Age of Marriage & & & & & 3.11 & 0.375 \\
\hline$<19$ & 11,998 & 41.1 & 1,349 & 4,6 & & \\
\hline $20-29$ & 13,292 & 45.5 & 1,583 & 5,4 & & \\
\hline $30-39$ & 817 & 2.8 & 91 & 0.3 & & \\
\hline$>40$ & 55 & 0.2 & 4 & 0.0 & & \\
\hline Number of Children Still Alive & & & & & 169.59 & 0,000 \\
\hline Nothing & 1,744 & 6.0 & 116 & 0.4 & & \\
\hline 1-2 children & 15,624 & 53.5 & 1,648 & 5,6 & & \\
\hline 3-4 children & 7,495 & 25.7 & 969 & 3,3 & & \\
\hline$>5$ children & 1,299 & 4.5 & 294 & 1.0 & & \\
\hline Residence Area & & & & & 2.12 & 0.146 \\
\hline Urban & 13,126 & 45.0 & 1,561 & 5.3 & & \\
\hline Rural & 13,036 & 44.7 & 1,466 & 5.0 & & \\
\hline Family Planning discussion & & & & & 7087.39 & 0,000 \\
\hline No Discussion & 1,257 & 4,3 & 1,599 & 5.5 & & \\
\hline Discussion & 24,905 & 85.3 & 1,428 & 4,9 & & \\
\hline Level of education & & & & & 15.38 & 0.002 \\
\hline No school & 349 & 1,2 & 67 & 0.2 & & \\
\hline Basic & 7,802 & 26.7 & 885 & 3.0 & & \\
\hline Intermediate & 14,061 & 48.2 & 1,631 & 5,6 & & \\
\hline High & 3,950 & 13.5 & 444 & 1.5 & & \\
\hline Job-status & & & & & 8.55 & 0.003 \\
\hline Work & 16,202 & 55.5 & 1,792 & 6.1 & & \\
\hline Does not work & 9,960 & 34.1 & 1,235 & 4,2 & & \\
\hline Method-Related Knowledge & & & & & 83.82 & 0,000 \\
\hline Don't Know Any Method & 49 & 0.2 & 34 & 0.1 & & \\
\hline Know the method & 26,113 & 89.5 & 2,993 & 10.3 & & \\
\hline Family Planning history & & & & & 1010.35 & 0,000 \\
\hline Never Use & 2,159 & 7.4 & 808 & 2.8 & & \\
\hline Have use & 24,003 & 82.2 & 2,219 & 7.6 & & \\
\hline
\end{tabular}


The ideal multivariate analysis modeling yields five variables that are proven to influence the incidence of unmet need. The influencing variables were the woman's age, the number of children still alive, family planning discussions, education level, and history of family planning use. This multivariate analysis can be used to obtain the variable that most influences unmet need in women of childbearing age by comparing the OR values in the modeling. The variable of family planning use history is the most influential variable on the unmet need for family planning. The variable history of family planning use is always significant in each model and has the highest OR (Table 3).

Table 3. Final Model Multiple Logistic Regression Analysis on Independent Variables Affecting Unmet Need for Family Planning

\begin{tabular}{|c|c|c|c|}
\hline Variable & $\mathbf{B}$ & p value & OR $(95 \% \mathrm{CI})$ \\
\hline Female Age & & 0,000 & \\
\hline $15-24$ & & & 1 \\
\hline $25-34$ & $-0,316$ & 0,000 & $0.729(0.625-0.850)$ \\
\hline $35-44$ & -0.129 & 0.121 & $0.879(0.747-1.034)$ \\
\hline $45-49$ & 0.218 & 0.27 & $1,243(1,025-1,508)$ \\
\hline Number of Childre & & 0,000 & \\
\hline Nothing & $-3,210$ & 0,000 & $0.040(0.030-0.055)$ \\
\hline 1-2 children & -0.773 & 0,000 & $0.462(0.386-0.552)$ \\
\hline 3-4 children & $-0,340$ & 0,000 & $0.711(0.597-0,847)$ \\
\hline$>5$ children & & & 1 \\
\hline Level of education & & 0.006 & \\
\hline No school & -0.059 & 0.738 & $0.942(0.665-1,335)$ \\
\hline Basic & $-0,114$ & 0.135 & $0.892(0.768-1.036)$ \\
\hline Intermediate & 0.075 & 0.280 & $1,078(0.941-1,234)$ \\
\hline High & & & 1 \\
\hline \multicolumn{4}{|c|}{ Family Planning discussion } \\
\hline No Discussion & & & 1 \\
\hline Discussion & $-3,002$ & 0,000 & $0.050(0.045-0.055)$ \\
\hline \multicolumn{4}{|c|}{ Family Planning history } \\
\hline Never Use & 1,836 & 0,000 & $6,269(5,416-7,257)$ \\
\hline Have use & & & 1 \\
\hline Constant & 0.753 & & \\
\hline
\end{tabular}

\section{DISCUSSION}

\section{Relationship between Age of Women and Incidence of Unmet Need Family Planning}

The unmet need can be experienced by women both at a young and old age. The study results found that unmet needs and women's age showed a significant relationship, where the older the woman was, the more risk she had for unmet need. The incidence of unmet needs in this study was experienced by women aged 35 44 years. The higher the age of the woman, the higher the woman's need for family planning.

These results are in line with the research Uljanah, Winarni, and Mawarni (2016), which shows that the age of women of childbearing age and the occurrence of family planning unmet need has a significant relationship. Women aged > 35 years experience a lot of unmet need for family planning. This is because people $>35$ years of age are not in their productive period, so they assume that if they do not use contraception by any method, there will still be no pregnancy. Therefore, women with older age have the highest chance of the unmet need for family planning. However, unmet need in a person does not have a specific age formula, but this occurs because of the wrong perception that the older the age, the lower the chance of pregnancy (Fitriyah, 2017).

This perception puts women of older age at risk for unmet need. Even though it is still possible for pregnancy to occur at that age, contraception is still needed to regulate or postpone pregnancy. But on research, 
Nurjannah (2016) said that unmet need FP incidence will be related to the age at which you want to limit births only, but not to spacing or delaying births. Therefore, it is still rare to use family planning as a birth restriction at the age of 15-34 years because they still desire to have children again.

\section{First Age Relationship between Married and Unmet Need Family Planning incident}

The analysis results found no relationship between the age at first marriage and the occurrence of unmet need for family planning. Unmet need for family planning is mainly experienced by women aged 20-29 when they first married. ResearchKatulistiwa, Baroya, and Wati (2014) also stated that between the age at first marriage and the occurrence of family planning unmet need in women of childbearing age did not show a significant relationship. Married women aged 20-29 years have a greater risk than married women aged $<20$ years. This condition, because the average age at first marriage is $20-29$ years, women still want to have and add more children, so they prefer not to use contraceptives.

The first age at marriage is when the opportunity to get pregnant and give birth begins. However, the age at first marriage is not a determining factor in the unmet need for family planning but rather determining infertility. This is because the younger a woman is, the higher the fertility rate will be. Where if the fertility rate is high, it will have an impact on increasing childbirths. Thus, contraceptives are more likely to be used by women who are married young (aged $<20$ years) to achieve the desired fertility preferences (Katulistiwa, Baroya, and Wati, 2014).

\section{Relationship between the number of children still alive and the incidence of Unmet Need Family Planning}

In this study, the unmet need for family planning was mainly experienced by women who had 1-2 children, while the least was experienced by women who did not have children. According to the analysis results, the results obtained are $p>\alpha(0.05)$, so it can be concluded that the number of children who are still alive at PUS will impact the occurrence of unmet need for family planning in women of childbearing age. The emergence of this unmet need can be caused by the community's culture, which still considers that male children are considered more valuable than women. The couples of childbearing age (PUS) who do not have boys in their families will continue to increase their children until they get children with the male gender (Nurjannah, 2016).

These results follow the research of Uljanah, Winarni, and Mawarni (2016), who said that the number of children still alive influenced unmet needs in women of childbearing age. This relationship is caused by the higher the number of children, and the more likely women are to exceed the desired fertility preference level. Thus, enabling them to experience the unmet need for Family Planning.

The number of still alive children can influence changes in family planning needs during a woman's reproductive age. A young woman has a goal to regulate birth spacing, whereas, in an older woman, it is more necessary to limit births after reaching the desired family size. Thus, the consideration in choosing the need for contraception must be well understood so that there is no unmet need for family planning in these women (Wulifan et al., 2016).

\section{Relationship between The Area of Residence and The Incidence of Unmet Need Family Planning}

The results said that between the area of residence and the occurrence of family planning unmet need in women of childbearing age did not show a significant relationship. The women of childbearing age who live in the city (urban) are more likely to experience unmet needs. Research result Rai and Ramadan (2018) also said that there is no relationship between the area where women live and the unmet need for family planning. The women of childbearing age who live in the city (urban) are more likely to experience the unmet needs 1,448 times than the women of childbearing age who reside in the village.

These results differ from the research of Zia (2019), where these results indicate a relationship between the area where women live and the occurrence of unmet needs. Where residents who live or are in rural areas have a higher chance of unmet need, people who live in villages are not exposed to health information, either through the mass media or from health workers. Thus, it allows them not to 
get good information regarding contraceptive methods.

\section{Relationship between Women of Childbearing Age Education Level and Family Planning Unmet Need Incidence}

The analysis results show that education at women of childbearing age affects unmet needs in women of childbearing age. The higher the education of women of childbearing age, the greater the risk of unmet need for family planning. Unmet needs in highly educated women can occur by other factors that influence. For example, when a highly educated woman has an adverse history of family planning use or experiences side effects from family planning, it will make her feel afraid to use the family planning program again.

Another factor can be work and economic status. A woman who has higher education and employment will improve her financial situation without having time to do family planning programs. Many women still believe that many children are sustenance, so they will not want to do family planning programs (Aidayasari, 2017). According to Sariyati, Mulyaningsih, and Sugiharti (2015), many women already know how to prevent pregnancy with natural methods, making them reluctant to use modern contraceptives anymore.

Meanwhile, the low level of education will be related to understanding health issues, including contraception. This is in line with Sarlis (2019) which says that education and the occurrence of unmet needs in women of childbearing age have a significant relationship, where education is an effort that can be used to change a person's attitude or behavior that lasts a lifetime to the desired direction. A person with high education will get a lot of information from various sources, guiding them in filtering the data to behave correctly and according to his wishes. Thus, high education in a person makes it possible to have broad knowledge compared to someone with low education.

According to research, Sariyati, Mulyaningsih, and Sugiharti (2015) said that a mother's education would make them have more health information. The information related to family planning that they have will also be better and will later make the mother's decision making appropriate to choose the contraceptive method to use.

\section{Relationship between Job Status and Unmet Need Family Planning incidents}

Work status in this study is related to the occurrence of unmet need Family Planning. The data shows that women of childbearing age who work are more likely to experience unmet needs, but this number is not much different from those who do not work. These results are not following Paramita, Thohirun, and Baroya's (2017) 's research, who say that homemakers are at higher risk of unmet need than working women. This is because working women have better health-related access to information than a housewife. Working women will also prefer to limit or regulate the desired pregnancy, not affect their work to pay more attention to contraception. This makes working women less likely to experience unmet need

Other factors can cause unmet needs for women because women's employment status can be identified as an additional important factor in the unmet need for family planning. Such employment status and income can increase women's authority to improve financial decision-making in their families. Women can regulate contraception and reduce the occurrence of unmet needs (Wulifan et al., 2016).

\section{The Relationship between Family Planning Discussions and Unmet Needs Family Planning Incidents}

Discussions related to family planning with a partner are essential because this will consider deciding something. This study shows that family planning unmet needs in women have a relationship with family planning discussions between partners. Unmet need for family planning is most often experienced by women of childbearing age who do not have discussions with their partners regarding family planning.

However, this is not following Fitriyah's (2017) research, which said that the discussion between family planning and the occurrence of unmet need for family planning at women of childbearing age did not have a significant relationship. This happened because the arguments built only emphasized the number and frequency of family planning use 
but did not dig deeper regarding the discussion.

Discussions about family planning among husband and wife couples are not the main factor in determining family planning, but it will become a barrier to using family planning if the husband and wife do not discuss it. Good communication between husband and wife can bridge the process of using and accepting family planning (Wahab, Fitriangga, and Handini, 2014).

\section{Relationship between women of childbearing age Knowledge and Unmet Need Family Planning incidents}

Knowledge-based research is referred to as women of reproductive age who have sufficient information about the types of family planning methods. Good family planning knowledge in a person should determine whether he or she is doing family planning or not according to his g oals, but vice versa if the knowledge is not good, then there will be a chance to unmet need (Fitriyah, 2017). The analysis resulted in a significant relationship between understanding childbearing age and the unmet need for family planning. The occurrence of unmet needs was mainly experienced by women with good knowledge of family planning methods. This can occur for other reasons, such as fear of contraceptive side effects, leading to reluctance to use contraceptive devices or methods.

These results are in line with the research of Sariyati, Mulyaningsih, and Sugiharti (2015), which shows that the occurrence of unmet needs in women of childbearing age is influenced by the knowledge possessed by women of childbearing age itself. Mothers who have the low ability will also have a common understanding of family planning so that a mother's opportunity to experience the unmet need for family planning will increase. The research result is contradicted research by Uljanah, Winarni, and Mawarni (2016), which said there was no significant effect between women of childbearing age's knowledge and unmet need. One's knowledge alone is not sufficient to get someone to perform a behavior. This happens because other factors can influence it, namely internal factors such as intelligence, one's perception, and motivation to do something. Meanwhile, external factors include economic, social, access to information, and local culture.

\section{Relationship History of Family Planning Use with Unmet Need Family Planning Events}

The experience of women of childbearing age in using contraception is very influential in determining the following contraceptive method or continuing or even stopping using contraception. Based on the study results, it was stated that the history of using family planning at women of childbearing age showed a significant relationship in the occurrence of unmet needs in women of childbearing age. Research data shows that most women of childbearing age have a history of using contraceptive tools or methods. Thus, it can be said that women with a history of using FP are more experienced than women who do not have an account of using any contraceptive tools or methods.

Research Nurjannah (2016) also said a significant relationship between family planning history and the occurrence of unmet need for family planning in women of childbearing age. The experience of women's failure in using contraception can make them think again in determining the right choice for the next contraceptive. According to research, Putro (2016) said when someone does not want to use contraception again, it could be due to an unpleasant experience with contraception. However, the results suggest that women who have no history of using birth control have a higher risk of unmet need. According to Kurniasih (2014), unmet needs in a woman can be caused by personal experience of contraception, friends' experiences, and rumors that often circulate in the community. The existence of negative stories or rumors about contraception can cause a woman who has no contraception experience to feel afraid to do the family planning program. Thus, it can be said that interpersonal influences in the form of experiences with oneself or others or negative rumors will affect individual beliefs and behavior in making contraception decisions. 


\section{CONCLUSIONS AND SUGGESTIONS}

\section{Conclusions}

Factors that have a relationship with the occurrence of unmet need for family planning are the age of the mother $(0.000<\alpha)$, the number of children alive $(0,000<\alpha)$, discussion of family planning $(0,000)<\alpha)$, an education level $(0.002<\alpha)$, employment status $(0.003<\alpha)$, knowledge regarding methods $(0.000<\alpha)$, and history of family planning $(0.000<\alpha)$. Meanwhile, the age at first marriage and residence area did not show a relationship with the occurrence of unmet need for family planning.

The analysis results also prove that the history of family planning between partners is the variable that most influences the occurrence of unmet need for family planning in women. The more women never do the family planning program, the greater the risk of unmet need for family planning.

\section{Suggestion}

Suggestions for health practitioners are to increase further the promotion of family planning programs to deal with unmet need incidents. It can be done by increasing health education activities by providing counseling and counseling to women and couples of childbearing age (PUS). Giving knowledge is related to the method and can provide adverse effects or issues in the contraceptive method that should be eliminated. The provision of these activities can be provided before the PUS is married. These activities can increase the partner's knowledge so that the couple can support their wife in doing contraception.

\section{REFERENCES}

Aidayasari, N., 2017. Factors Affecting Unmet Need in Fertile Age Couples, Prawirodirjan Village, Yogyakarta. Publication Manuscript.

Bappenas, 2018. Development Demographics. Jakarta.

BKKBN, 2009. The number of Active Family Planning Participants (PA) Against PPM-PA Per Province 1999-2008. Jakarta.

BKKBN, 2015. Strategic Plan of the 2015-2019 National Population and Family Planning Agency. Jakarta.
BKKBN, 2018. The Number of Unmet Needs in Indonesia is Still High. Jakarta.

BPS, 2013. Indonesian Demographic and Health Survey C102. Jakarta.

Dariani, L., 2015. Factors Associated with Unmet Need for Family Planning in Fertile Age Couples.

Fitriyah, N., 2017. The Choice of Husband's Fertility and Family Planning Needs for Fertile Age Couples in Indonesia (2007 IDHS Data Analysis). Andalas Public Health Journal, 11 (1), pp. 4954.

Katulistiwa, R., Baroya, N. and Wati, DM, 2014. Determinants of Family Planning Unmet Needs in Married Women in Klabang District, Bondowoso Regency. e-Journal of Health Literature, 2 (2), pp. 277-284.

Kurniasih, E., 2014. The Unmet Need Behavior of Women in Fertile Age. Journal of Med Science, 7 (1), pp. 12-19.

Nurjannah, SN, 2016. Unmet Need Incidents in Women in Fertile Age Couples in Kuningan, West Java. Midwife Journal, 2 (1), pp. 23-33.

Paramita, DF, Thohirun and Baroya, N., 2017. Relationship between Women's Autonomy and Perceptions of Family Planning Counseling Services and Unmet Needs for Family Planning in Fertile Age Couples in Sumberjambe District, Jember Regency. e-Journal of Health Literature, 5 (2), pp. 214-222.

Putro, DA, 2016. Unmet Need for Family Planning in Urban and Rural Areas in the Province of Yogyakarta Special Region. 1 (April).

Rai, A. and Ramadhan, RR, 2018. Factors Influencing Unmet Need Family Planning in Bengkulu Province in 2015 Using Binary Logistic Regression Modeling. Indonesian Journal of Statistics and Its Applications, 2 (1), pp.46-55.

Sariyati, S., Mulyaningsih, S. and Sugiharti, S., 2015. Factors Associated with Unmet Need for Family Planning in Fertile Age Couples in Yogyakarta City. Journal of Nurses and Indonesian Midwifery, 3 (3), pp. 123128.

Sarlis, N., 2019. Factors Related to Unmet Need for Non-acceptors in 2018. Journal of 
Endurance, 4 (2), p. 272.

IDHS, 2017. Indonesian Demographic and Health Survey 2017.

Stephenson, R., Beke, A. and Tshibangu, D., 2008. Community and health facility influences on contraceptive method choice in the Eastern Cape, South Africa. International Family Planning Perspectives, 34 (2), pp. 62-70.

Uljanah, K., Winarni, S. and Mawarni, A., 2016. The Relationship of Risk Factors for Unmet Need Family Planning (Family Planning) Incidents in Adiwerna Village, Adiwerna District, Tegal Regency, Quarter III 2016. Public Health Journal, 4 (4).

Wahab, R., Fitriangga, A. and Handini, M., 2014. The Relationship Between Wife's Knowledge Factor and Husband's Support Against Unmet Need Family Planning in Fertile Age Couples in Siantan Tengah
Village, North Pontianak District, 2014. 80 (2), pp. .702-712.

WHO, 2013. Guidelines for Preventing Early Pregnancy and Poor Reproductive Outcomes among Adolescents in Developing Countries.

Wulifan, JK, Brenner, S., Jahn, A. and De Allegri, M., 2016. A Scoping Review on Determinants of Unmet Need for Family Planning among Women of Reproductive Age in Low and Middle-Income Countries. BMC Women's Health, 16 (1).

Zia, HK, 2019. Relationship of Education Level, Residence and Information of Family Planning Field Officers on Unmet Need for Family Planning for Married Women. Indonesian Journal of Public Health, 14 (1), pp. 155165. 